\title{
Coherent fiber supercontinuum laser for nonlinear biomedical imaging
}

Tu, Haohua; Liu, Yuan; Liu, Xiaomin ; Lægsgaard, Jesper; Turchinovich, Dmitry; Boppart, Stephen A.

Published in:

Proceedings of SPIE - The International Society for Optical Engineering

Link to article, DOI:

$10.1117 / 12.999522$

Publication date:

2012

Link back to DTU Orbit

Citation (APA):

Tu, H., Liu, Y., Liu, X., Lægsgaard, J., Turchinovich, D., \& Boppart, S. A. (2012). Coherent fiber supercontinuum laser for nonlinear biomedical imaging. Proceedings of SPIE - The International Society for Optical Engineering, 8553, 85530A. https://doi.org/10.1117/12.999522

\section{General rights}

Copyright and moral rights for the publications made accessible in the public portal are retained by the authors and/or other copyright owners and it is a condition of accessing publications that users recognise and abide by the legal requirements associated with these rights.

- Users may download and print one copy of any publication from the public portal for the purpose of private study or research.

- You may not further distribute the material or use it for any profit-making activity or commercial gain

- You may freely distribute the URL identifying the publication in the public portal

If you believe that this document breaches copyright please contact us providing details, and we will remove access to the work immediately and investigate your claim 


\title{
Coherent fiber supercontinuum laser for nonlinear biomedical I imaging
}

\author{
Haohua Tu, ${ }^{1}$ Yuan Liu, ${ }^{1}$ Xiaomin Liu, ${ }^{2}$ Jesper Lægsgaard, ${ }^{2}$ Dmitry Turchinovich, ${ }^{2}$ Stephen A. Boppart ${ }^{1}$ \\ ${ }^{1}$ Biophotonics Imaging Laboratory, University of Illinois at Urbana-Champaign, Urbana, Illinois 61801, USA \\ ${ }^{2}$ DTU Fotonik, Technical University of Denmark, DK-2800 Kgs. Lyngby, Denmark
}

\section{0-word abstract}

Nonlinear biomedical imaging has not benefited from the well-known techniques of fiber supercontinuum generation for reasons such as poor coherence (or high noise), insufficient controllability, low spectral power intensity, and inadequate portability. Fortunately, a few techniques involving nonlinear fiber optics and femtosecond fiber laser development have emerged to overcome these critical limitations. These techniques pave the way for conducting point-of-care nonlinear biomedical imaging by a low-maintenance cost-effective coherent fiber supercontinuum laser, which covers a broad emission wavelength of 350-1700 nm. A prototype of this laser has been demonstrated in label-free multimodal nonlinear imaging of cell and tissue samples.

\section{0-word abstract}

The last decade has witnessed an increased application of femtosecond (or picosecond) solid-state lasers and closely related optical parametric oscillators (or amplifiers) in label-free biomedical imaging. Representative techniques include multiphoton autofluorescence, stimulated Raman scattering, stimulated emission, and nonlinear absorption. With the rapid advancement of ultrafast spectroscopy, similar molecular specific nonlinear imaging techniques will continue to emerge. However, ultrafast solid-state lasers are often bulky, expensive, and alignment-sensitive, restricting these techniques to dedicated optical laboratories. Also, daily laser operation demands training and experience far beyond that of regular clinical staff. To translate these techniques to the clinic (e.g., point-of-care diagnosis and imaging), there is a critical need to replace the solid-state lasers with portable, low-cost, lowmaintenance, and environmentally-stable fiber lasers.

Unfortunately, conventional ultrafast fiber lasers have narrow gain bandwidth, so that the emission is typically limited to a few discrete wavelengths of rare earth dopants, such as 1040 nm (Yb), 1550 nm (Er), and $2000 \mathrm{~nm}(\mathrm{Tm})$. To address this key limitation, we have developed a supercontinuum source based on dispersion-engineered photonic crystal fibers, which converts $1040 \mathrm{~nm}$ femtosecond pulses (pump) to a targeted wavelength (signal) anywhere inside the UV-visible-IR region of 350-1700 nm. In sharp contrast to traditional supercontinuum generation that loses coherence between the pump and signal, this source preserves the coherence, and thus behaves like a fiber analogue of optical parametric oscillators. The demonstrated frequency up- and down-conversion of a fixed-wavelength ultrafast fiber laser facilitates the envisioned clinical translation of this coherent fiber supercontinuum source for nonlinear biomedical imaging. 